\title{
Schmidt Péter
}
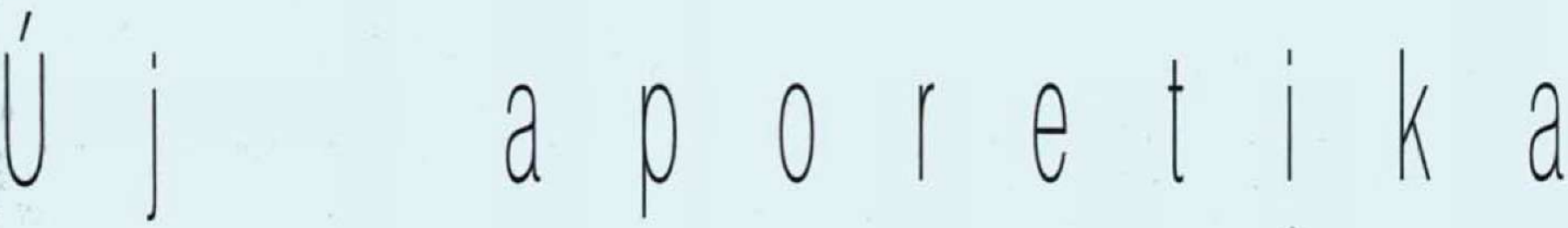

"Az a tény, hogy a filozófiának tulajdonított összes eddigi föladatok, a kompenzációs funkció, a fölvilágosítási szolgáltatás és a cselekvési intenció egyaránt elégtelennek bizonyult, s nem volt képes föltartóztatni a filozófia bizalomvesztését és imázs-eltúnését, úgyhogy a filozófiának, ha azt akarja, hogy még egyáltalán komolyan vegyék, tudományos vagy ideológiai-politikai köntösben kell föllépnie, kézenfekvóvé teszi azt a következtetést, hogy a filoź́fia alapjai kerültek válságba. (...) És az, ami kudarcot vall, nem a filozófia egyáltalán, az ember eredeti filozofálási igényének értelmében, hiszen különben nem lehet megérteni a diákok egyre növekvó számát és az egyre növekvố keresletet a távol-keleti bölcsesség iránt, hanem egy bizonyos filoz6́fiatípus az, ami kudarcot vall, mégpedig a nyugati ..."

/Karen Gloy [4]/

\section{'Kezdeni' 'tudni' 'kell'.}

Tudni elkezdeni.

Kimondani a "legyen" $t$.

Létrehozni a semmibốl valamit, a nem-létezốt létezóvé tenni. Hiszen a legyen (Sollen) mindig is annak az igénynek a megnyilvánulása, hogy más legyen, mint ami van. És ezzel együtt mi is mások legyünk. A kezdeni-tudás tehát változtatni-tudás, a legmagasabb rendú isteni tudomány, az önkény és erószak tudása, a feltétlen teremtó hatalom. Az embernek a legyen kell, hogy istenné legyen.

A kérdés csak eż után jöhet.

A kérdezni-tudás a legmagasabb rendú emberi tudomány. Az embernek a kérdés kell, hogy emberi legyen - most, miután a válasz már adott.

Eddig a filozófia.

II.

A filozófia egyetemes tudásként definiálta önmagát (és teszi ezt a mai napig), amikor azzal az igénnyel jelentkezett, hogy mint tudás mindent a tárgyául fogad. Ezt úgy próbálta elérni, hogy a mindent ( $\tau \dot{\alpha} \pi \sigma^{\prime} v \tau \alpha$ ) fogadta tárgyául.

A filozófia számot ad tudásáról. A tudás a filozófia tudása, tehát a tudás nem azonos a filozófiával. Tegyük fel tehát a kérdést: mi a tudás ?

Aki nem tudja, az nem keresi.

Aki úgy tudja, hogy nem tudja, az máshol keresi.

Aki ágy tudja, hogy tudja, az önmagában keresi.
Aki tudja, az nem keresi.

"Valamit már tudni kell (vagy: valamire képesnek kell lenni) ahhoz, hogy a megnevezésre tudjunk kérdezni. De mit kell tudni 2... Azt mondhatjuk: értelmesen csak az kérdezi meg valaminek az elnevezését, aki már tud is vele valamit kezdeni." [18]

A tudás nem fizikailag ragadható meg, így nem birtokba vehetố, hanem elsajátítható. A tudás elsajátítása "szellemi cselekvés", akkor is, ha a tudás nem ismeretszinten jelenik meg (mint pl. cselekedni-tudás, élni-tudás stb. vö. [8]). A tudás nem "anyagi szinten tárolódik" (a mesterséges intelligencia nem tudás); aki tud, az a tudatában (-val, -ként) tudja a tudását: "A mód, ahogy a tudat van, és ahogy valami a számára van, a tudás." [11]

A tudás nem pusztán tudattartalom: maga is formálja a tudatot; a tudat ennyiben anyaga a tudásnak, amely ennyiben formája a tudatnak. A tudás "egy szubjektumban megtestesüló egyedi forma, amely az azt konstituáló különbözó kompetenciákból tevódik össze." [8] A kérdés mármost az, hogy ez az egyedi forma miképpen is válhat egyetemessé.

A tudás semmiféle érvényességre nem tesz szert azáltal, hogy elmondják. Amit elmondanak az nem a tudás, a tudás az elmondásban nem nyilvánulhat meg. "Mit jelent tudni, de nem tudni megmondani ?" [18]

Pedig a tudásnak lényege a megnyilvánulás. A tudás csak a megnyilvánulás által az, ami. A megnyilvánulás mint lényegi mozzanat által nem a megnyilvánultság mint létmód, hanem a tudásban benne lévó, az általa lényegileg hordozott jelenik meg.

A tudás a tudás alkalmazásában nyilvánul meg - a tudás alkalmazását gyakorlatnak nevezem. [3] A tudásra mindenki alkalmazhatósága miatt vágyik. Akkor is, ha ez az alkalmazás "pusztán" a birtoklásából fakadó boldogságot jelenti - ti. ekkor úgy alkalmazom, hogy felidézem azt, hogy tudom (vö. p.c. [1]). A tudás egyben alkalmazni-tudás is, tudnom kell tehát, hogy $\mathrm{mit} / \mathrm{mihez} \mathrm{kezdjek} \mathrm{vele.}$ 
III.

A tudás átadása eredendóen felmutatás, bemutatás, elsajátítása pedig eredendốn utánzás, ismétlés (Wiederholung). "Mert azokat a dolgokat, amelyeket elózetes tanulás révén kell létrehozni, azokat éppen a létrehozó tevékenység révén tanuljuk meg." [1] E folyamat segítóje a verbális kommunikáció, a beszéd. E folyamat eredendó tényezói a szituáció, az átadó és az elsajátító. A folyamat létrejöttéhez szükséges e három tényezó együttes (térben és idóben egyszerre való) jelenléte. Az átadó alkalmazza a tudását a szituációban, az elsajátító pedig megpróbálja ốt utánozni. A megértés meggyorsítása érdekében az átadó kommunikálja a tudás alkalmazásában érzékszervekkel nem megragadható mozzanatokat (pl. gondolatait). Ha a szituáció távol marad, a beszéd szerepe kiemelkedik, mert a szituáció modelljét és az abban való mozgást is, tehát az egész tudást a kommunikációs csatornába próbálja az átadó belesúríteni, ez a verbális információhalmaz azonban már nem a tudás, csak annak látszata. A tudás látszata, minthogy eredendó megjelenési formája közvetlenül már nem adódik számunkra, elsódleges fontosságúvá, így számunkravalóságában tudássá válik. A tudásról való tudást tudomásnak neveztem el.

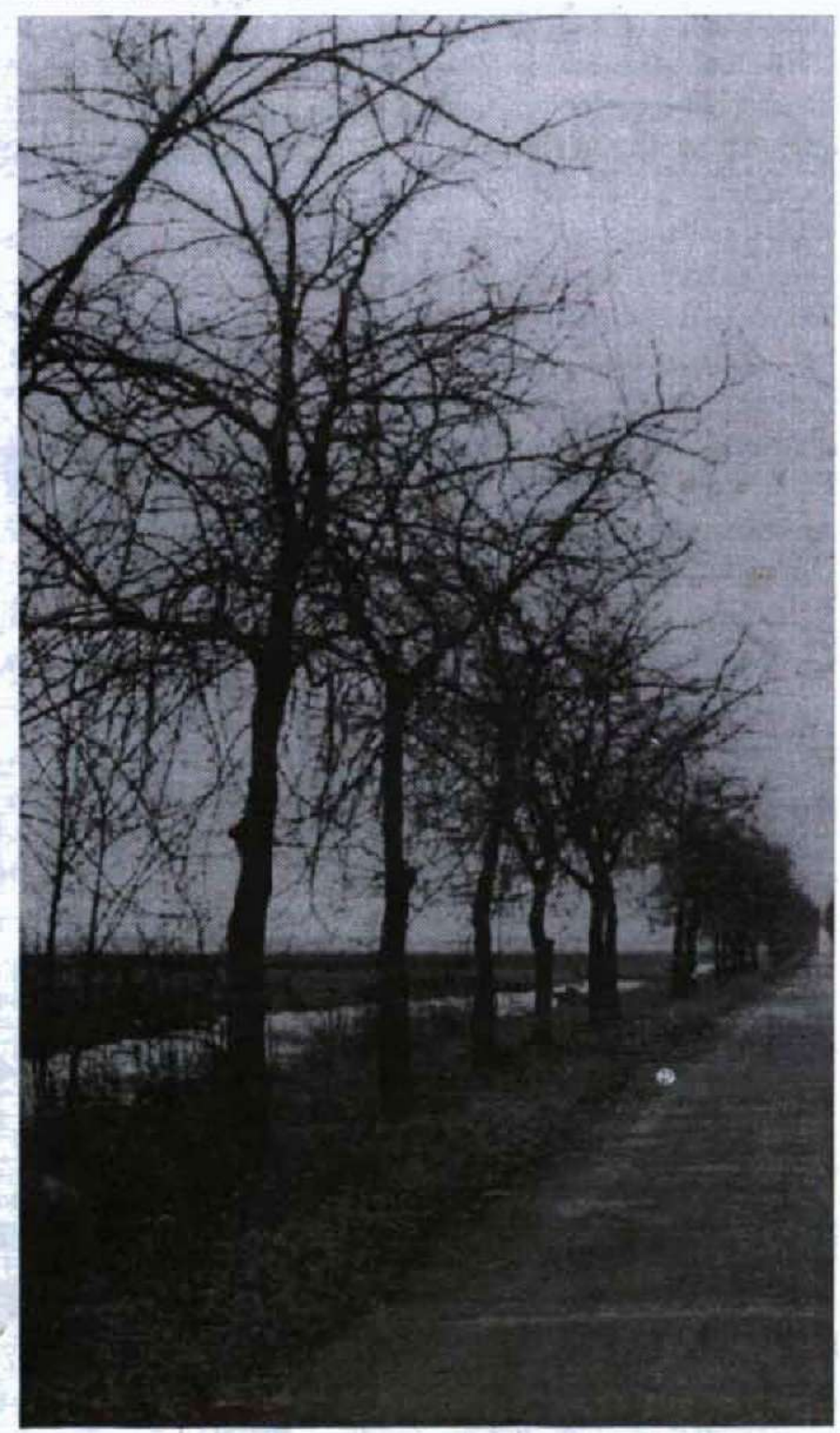

Szükségesnek tartom tudás és tudomás elkülönítését.

A tudomás sajátos tudásforma, amelynek a tárgya a tudás. A beszédben megnyilvánuló tudás a puszta beszélni-tudás, amirôl szó van: a tudás, ami viszont megjelenik a beszéd által: a tudomás. Tudok valamir, tudomásom van valamirố - eltéró a közvetetlenség mértéke. A tudatosság a tudás reflektált megnyilvánulása, tudatosság tehát akkor van, ha tudás és tudomás egyưtt múködik.

\section{IV.}

A szellemi ismeretté változott tudás által a filozófia egyetemes igényeket felmutató elméletté válik. Egyetemes igényeitól hajtva önnön "tudathasadását" elméleti és gyakorlati filozófiaként jeleníti meg, ám a gyakorlati filozófia már eleve csak a gyakorlat filozófiájaként, tehát a gyakorlat elméleteként jelentkezik; maga a gyakorlat örökre eltúnik a filozófiából. Arisztotelész etikája csak arra vallalkozik, hogy elmondja, mit jelent erényesnek lenni, de arra már nem, hogy az olvasót erényessé tegye (vö. p.c. [13] ).

Ugyanekkor a tudást még mindig a maga teljességében szeretnék átadni. Az elmélet puszta átadását oktatásnak nevezhetjük, magának a tudásnak az átadását pedig nevelésnek, noha ez a nevelés már Arisztotelész korában illuzórikus. [1] A nevelés fogalma csakhamar az oktatás és szoktatás egységfogalmává válik - ez az, amit Wittgenstein rámutató tanitásnak, még inkább idomításnak nevez. [18]

A tudomásról a beszéd ad számot, mégpedig a tudásról szóló beszéd. Már maga a tudás is hátrahúzódik és elrejtốzoödik. [5] A gyakorlat helyébe az életbölcsesség lép.

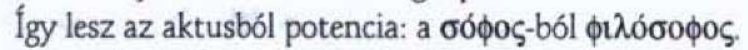

Ez a tudás (voltaképpen tudomás) intézményesülhet, mivel a szituációtól teljesen függetlenné vált. A tudomás már írásban rögzíthetố, amellyel az átadó és az elsajátító együttlétének szükségessége is kiküszöbölódik, ám az így konzervált tudás már nem a társadalmi és szellemi fejlốdéssel együttmozgó tudás, ami rövid idốn belül szétszaggatja s ezáltal idóbeliségétôl megfosztja a tudást. A tudás történetiségének megszüntetéséból születik meg a tudás története, a történeti tudás. "És csak az írás létrejöttével... lesz elsó ízben lehetséges a kimondott gondolat pontos, tárgyiasitott reprezentációja. Így áll eló a kognitív szubjektum ama távolsága saját mentális tartalmaitól, ama szellemi tér, melyben fogalmiság és reflexió elóször kibontakozhatnak. Kialakul az ellentmondás és a koherencia eszméje, formát ölt a kritikairacionális gondolkodás." [9]

A szóbeliség és az írásbeliség kultúrái közötti különbséget csak az elektronikus médiák korában fedezték fel, éppen azáltal, hogy e korszak a létében az írástól függó ún. "másodlagos szóbeliség" létrejöttének kora. [12] Egyre inkább teret hódítanak a nem természetes, közvetlenül az értelemtól származó (grown directly out of consciousness) nyelvek, amelyek által végképp megszưnik minden értelmen túli ("transzcendentális") tudás. A "tudatos" nyelvhasználat a másodlagos szóbeliség elsódleges (eredendó) jellemzóje, ám ez a tudatosság nem a nyelv használatára, hanem nyelviségére vonatkozik. Tudásunk pusztán nyelvtudás.

Kant ismerte fel, hogy az értelem áll az embernek a képzeteket szekventáló, osztályozó, elvont-egyoldalúan analizáló 
tevékenysége mögött: Az értelem az irásbeliség ${ }^{1}$ által a trónra ültetett zsarnok, aki azonban tudást adni önmaga nem képes. A kimúvelt (literate) értelmi ember feladja valóságigényét, megelégszik azzal, hogy a valóság vetūleteit szemlélję; a szemlélódó filozófus már nem lát - értelmi, de már nem értelmes ember (homo sapiens). Az értelem hierarchiákat rōgzít, a valóságot viszont a kölcsönösség hatja át. Az irásbeliség rigid linearitása tehát eleve inadekvát forma a tudás rögzítésére. A XX. századra "fejlódik ki" a filozófia torzója: az analitikus filozófia, noha ekkor már ismert a valóság illogicitása ${ }^{3}$. Az írott hagyományon belül a legtartalmasabbak mindig az elsố szóbeliség kultúráját rögzító "termékenyen ellentmondásos" múvek, illetve a még mindig az egység igényét hordozó, de már az írásbeliség korabeli kanti körmondatok.

Schnädelbach fogalmazza meg félreérthetetlenül a filológiára támaszkodni kénytelen elmélet távolmaradását a tudástól. [16] A filológiai filozófia-hagyomány nem feltétlenül a voltaképpeni filozófusokat közvetíti számunkra, pontosabban csak az e hagyományon belül legkiemelkedóbbeket képes közvetíteni. A hermeneutika betegének lázálma: az egyetemes tudás értelmében értett filozófia utolsó nyugati tanítója a számunkra adott hagyományon belül Szókratész

A tudomány a tudomás intézményesülése, a tudományos tudás tehát sajátos tudomásforma. Az elméleti ismeretek osztályokba sorolódnak, résztudományok, szaktudományok jelennek meg. A filozófia igyekszik megórizni egyetemes jellegét, s egyre altalánosabb tézisekben próbálja átfogni a világot. Elvonatkoztat, ezáltal egyoldalúsít; a közvetlenül adott, a konkrét háttérbe szorul.

(A "valami éppen elveszik" érzése a valamikorihoz való mind erósebb visszanyúlást követeli meg. A valamikori filozófiai hagyománnyá válik. A filozófia önmagáról a hagyományon keresztül próbál számot adni, megpróbál visszanyúlni az elé a tradició elé [6], amely reánk már csak a filozófia szigorúan elméleti meghatározását hagyta; a filozófiatörténet a filozófiába integrálódik.)

A konkréttól való elszakadás, a gyakorlat eltúnése és a szaktudományoktól való eltávolodás miatt a filozófia bevallottan öncélúvá kezd válni, ezáltal azonban a filozófus helye a társadalomban funkcionális kérdojjelet kap, és amikor a filozófia önmagát a szolgaleánysorból felszabadultnak deklarálja, azon nyomban rákényszerül, hogy önmagát a társadalom számára legitimálja. Ráadásul ez a társadalom éppen elveti a hagyomány legitimációs erejébe vetett meggyốzódését.

A filozófia önlegitimációs kísérletei két irányban indulnak el. Elóször megpróbál a szaktudományok mellett egyenrangú helyet kiharcolni - noha ezt önmaga fundamentalitásának hangsúlyozásával már eleve nem egyenrangúnak állítja be a maga javára -, és metodológiai jegyeket felvéve próbálja önmagára is alkalmazhatóvá tenni az institutio értelmében vett tudomány fogalmát, amelyet magát is - szakítva a hagyománnyal - e jegyek alapján definiál; egyben pedig módszerében vagy legalább módszerességében az elfogadott legabsztraktabb résztudományhoz, a matematikához próbál hasonlóvá válni. Késóbb e törekvések mellett tárgyi jellegư legitimációs eljárásokkal járul a társadalom elé, amikor is életproblémákat adaptál, és ezáltal újra közeledni kíván a gyakorlathoz: megjelenik az életfilozófia. Ez utóbbi azonban az intézményi léttel eleve inkompatibilis, ezért a tekintélyüket féltó metodológiai iskolák tốle azonnal elhatárolódnak.
Russell a misztikus módszert az élethelyzetekhez utalja, az életproblémákat viszont kitiltja a filozófia köréból. Az erkölcs fogalmát sajátosan érti, filozófia-képéból számúzi mint oda nem illót. Miután számára a módszer evidens garancia, vagy legalábbis kizárólagos alternatíva a tudás megszerzésére, szembehelyezkedik a hagyománnyal, ami pedig a szaktudományok esetében sem tehetó meg azok kummulatív jellege miatt. Álláspontja abból a helyes meglátásból táplálkozik, hogy az átlagember számára a tudományokat a mindennapokban hasznos technikai eszközök legitimálják, s ebból arra a helytelen következtetésre jut, hogy a filozófia mint logicizmus a szaktudományok organonjaként ismertethetó el a társadalomban. [15]

Weber radikális álláspontja tarthatatlan, mert a filozófia mint tudás mindig is a világban való eligazodás tudása; Weber mindazonáltal helyesen diagnosztizálja, hogy a tudás átadása a szaktudományokhoz igazított egyetemi kereteken belül lehetetlen, illetve, hogy ennek a tudásnak az intézményesülése jogtalan. [17] $\mathrm{Az}$ egyetemre sohasem a filozófia mint tudás, mindig csak a filozófia mint kutatás kerülhet be.

A metodológiai legitimáció legkiforrottabb képviselói a badeni neokantiánusok. A tudományosan megalapozott kultúrfilozófia létrehozására irányuló törekvésük a tudományosság- és világnézet-igény együttes kielégítését célozza, ám ez a dolog természetéból fakadóan nem sikerülhet. Rickert zseniális ötlete szerint a filozófia önnön passzivitását világnézetként állítja, amivel egyszerre küszöböli ki a gyakorlat gyakorlati felmutatásának szükségességét és teremti meg a gyakorlattól való elszakítottság látszatának látszatát. Íme a rickert-i circulus vitiosus: ".. a tudomány ... az intellektus által realizálódik. (...) Ezzel együtt az intellektus éppen a tudomány segítségével képes valami olyanra, ami csak az ó sajátja, és amely képessége éppen azon alapul, hogy elmélkedni tud az összéletrốl ..." Rickert posztulálja az elmélet és a gyakorlat a priori elszakítottságát: "Csak ... egyoldalúan elméleti beállítottsággal, mindennapi életūnk érdekei által nem befolyásolva vagyunk képesek mindenoldalúa elmélkedni a totalitásában létezó világról. (...) A filozófus csak akkor foghat hozzá egyetemes feladatának megoldásához, ha sikerül elvonatkoztatnia tulajdon "egzisztenciájától", ha tehát az "egész"-ben gondolkodva felülemelkedik a mindennapi életen. (...) ... amíg a világ megismerésére törekszünk, addig nem akarhatunk abban egész emberként "élni" vagy "egzisztálni" is. (...) A filozófiát mint egy sajátos tudományt szigorúan el kell különítenünk a mindennapi élettól (ganzes Leben) ..." Ezzel együtt ó az, aki a XX. században a legeróteljesebben hangsúlyozza annak szükségességét, hogy minden tekintetben megfeleljünk az egyetemesség követelményének. [14]

A tudás átadhatóságának a problémája a végletekig kiélezódik tehát, miután mindenkinek a számára egyértelmûvé vált, hogy a filozófia egyetemes tudásból egyetemi tudománnyá lett. Miképpen tünt eló a dologban a dolog természetétố idegen ? A látszattudás által. Éppen a tudás fentebb leírt elrejtózködése teremtett arra lehetóséget, hogy a pozitívum a tagadás tagadásaként jelenhessen meg; ezt a lehetóséget Hegel beteljesíti. "Hegelnél tehát a tagadás tagadása ennélfogva nem az igazi lényeg igazolása, éppen a látszat-lényeg tagadása által, hanem a látszat-lényeg, vagyis a magától elidegenült lényeg igazolása a tagadásában ..." [11] "Íme a filozófia, mely - abszolút újdonság volna ez? - saját visszajáró lelkévé válik: inkább kisért, mint lakozik saját helyein." [2] 
A filozófiai önreflexió alapvetó kategóriaterméke a szabadság.

A kanti morálfilozófia kísérlet a filozófia felnótt tudománnyá tételére.

Filozófiai indíttatásról ma is csak akkor beszélhetūnk, ha morális motívumok fordítanak valakit e felnốtt tudásforma felé. A felnótt tudásforma nem az egyetemi filozófia tudása. A filozófiai igény többre vágyik, mint filozófiára: valami több-mint-filozófiára. Az eredeti értelemben vett tudást keresi.

A tudás tehát több-mint-filozófiai tudás, ettốl lehet egyetemes; ettố lehetséges róla-tudás (tudomás), ami már "csak" filozófia. Tudunk róla, de többet akarunk: tudni akarjuk. Ha tudni fogjuk, akkor fogunk tudni.

A tudás elsajátítása a vélt passzív befogadás helyett egy dinamikus agresszió, a tudásvágy a hatalom akarása, hiszen a tudás hatalom önmagunk (és a világ) felett. A bennünk lévố másik embert akarjuk a hatalmunkban tartani, mert végso soron így lehetünk csak önmagunk. A tudás elsajátítása tehát önelsajâtitís. Vissza kell jutnunk önmagunkhoz!
A filozófiával szemben támasztott eredendó igény, hogy a filozófia vezessen el az önismerethez. "Az önismeret akkor valóságos, ha már életünk minden pillanatában bele tudjuk helyezni magunkat abba a közegbe, ami fenntart." A filozófia tehát az öntudás, azaz az egzisztáló öntudat. A filozófus a tudatosságra törekszik, a filozófus végsó soron nem beszél a tudásáról, hanem megjeleníti, képviseli azt. A filozófiai tudás maga a filozófus. A tudás átadása csak közvetlenül történhet, mert a tudás csak a világhoz való közvetlenségében az, ami. A tudás átadása csak az átadó szigorú jelenlétében lehetséges, a tudás közvetíthetetlen, mert kōzvetítettségében elvész. A nyugati iskola-rendszer már eleve nem volt kompetens a tudás átörökítésében.

A filozófia eredeti értelemben vett átadása önátadás. Az ōnátadás azonban mindig több mint önmaga. Nem adható át, csak ha túlmutat önmagán. A tudásként múködóképes tudás mindig is egy implicit imperatívusz, utánzásra-késztetó, példaszerú megnyilvánulás. "Egy példa mindig túlmutat önmagán: ezáltal végrendeleti dimenziót nyit. A példa mindenekelốtt másoknak szól, túl önmagunkon. A példa adója csak néha, vagy talán sohasem ér fel az általa adott példához, még ha elózóleg mindent elkövet is, hogy igazodjék hozzá, "megtanuljon élni", mondanánk, az általa adott példa tökéletlen példájaként. Adni azt adja tehát, amije nincs, sốt, ami ó nem." [2]

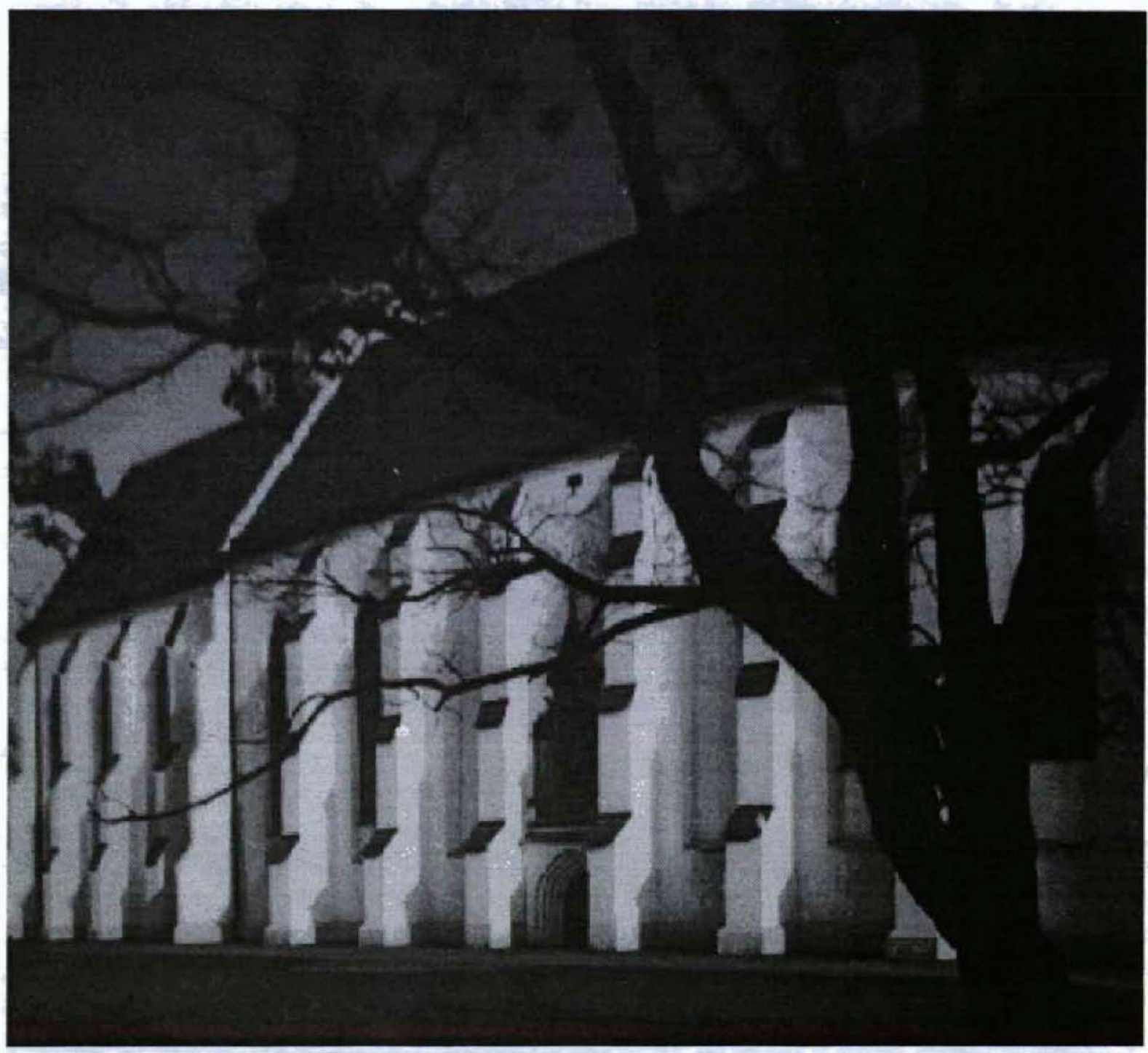


VI.

A nem polgári, avagy "a forradalmi" Heidegger és a nem-polgári, avagy "forradalmi" Lukács egyaránt a gyakorlat visszanyeréséért küzd, céljuk egyaránt a filozófia produktív tudománnyá való átalakítása. Ezért jelentkezik egyfelól a teória mint a praxis legmagasabb megnyilvánulása, a cselekvó nem-tágítás és a tudomány mint formáló eró, sốt a néppel együtt cselekvó́ tudás [6] - másfelól a látszattudományos szemléletmóddal szemben a tudás történeti-dialektikus jellegének kidomborítása és újra a kategórikus imperativusz: a 11. Feuerbach-tézis. [7] A szándék mindkét esetben egy hatékony, mobilizálható, mozgó tudás lehetóségének a felmutatása. Nagyon erốs legitimációs érvek: a tudomány mint szolgálat [6], illetôleg a(z) (ön)megismerés mint a praxis elófeltétele, s ezáltal létszükséglet a proletariátus számára [7]. Ám a beszéd csak beszéd marad.

Lyotard filozófiája már csak a tudomány legitimációs aktusa. "A legitimáció metanarratív apparátusának elavulása egybeesik a metafizikus filozófiának és az arra alapozott egyetemnek mint intézménynek a válságával. A posztmodern tudás finomítja a különbségek iránti érzékenységünket, és erósíti az összemérhetetlenség iránti türelem képességét." [8]

A tudás informatikai áruvá válik, és ekként a munkaidó mint értékszubsztancialitás helyébe lép. Látványosan végbemegy az, amit Marx egy évszázadra elóre megjósolt: "a munkás a termelési folyamat mellé lép, ahelyett, hogy fó ágense lenne." [10] Sajátos munkájában egy emberfajta eleve ebben az állapotban nó fel - és ez a filozófus. Az eredeti (naiv) elvárás szerint a filozófus embertermeló ember (vö. [13]), és míg a mindenkori egyén egyéni munkája önmaga újratermelése, nembeli munkája pedig önmegvalósítása, a filozófus egyéni munkája az ember nembeli újratermelése lenne. A klasszikus görög bölcselet a bizonyítéka annak, hogy ennek a munkának lehetetlen megfelelni az intellektus szintjén.

Az információ korában a tájékozódási válság elkerülhetetlen, hiszen "mind rövidebb idốszakokban mind nagyobb információmennyiséget kell áttekinteni ahhoz, hogy döntéseket lehessen hozni", s a permanens értékváltozás, az érvényes normák és az igazságszolgáltatás relativizálódásának szükségszerú következménye a mindenoldalú dezorientáció. [4]

Az oktatás elófeltétele a szakértốk által már vita nélkül elfogadhatónak nyilvánított igaz kijelentések megléte, azaz a tudományos hagyomány megléte (vö. p.c. [15] ). Persze a filozófiában effajta hagyomány nem jöhet létre, hiányzik hozzá a szakértói konszenzus. A szakértói konszenzus a mai tudomány önlegitimációs aktusa. A tudományos tudás - megszorításai révén intézményesülhet, ám ezzel viszonya a társadalomhoz külsódlegessé válik. Az egyetemes tudás nem intézményesíthetó.

A tudásfogalom Lyotard által leírt metamorfózisának következményei: tömegképzés, funkcionális céltudás, a technokrata elit és a professzionális értelmiségi konfliktusa, az oktatás gépesítése, a tudós egyetlen funkcionális társadalmi státuszlehetóségének (ti. a tanári pozíciónak) a felszámolódása. [8] De mi már tudjuk, hogy ez a filozófia számára nem baj, hanem egyenesen az üdvösség lesz. Ebben a helyzetben ugyanis az egyre fogyat- kozó professzionális értelmiségi réteg egyetlen lehetôsége, a Heidegger által megfogalmazott szabadság [6] kiharcolása önmagának törvényt adni - lehetetlenné válik. Az egyetemi szervezódés felbomlik, az egyetemes tudás klasszikus átörökítési formái újra elterjedhetnek, és elkezdódhet végre a filozófia ...

1996.

$J$ e g y z e t e k

1. ... abstractly sequential, classificatory, explanatory examination of phenomena or of stated truth is impossible without writing and reading." [12]

2 "Though words are grounded in oral speech, writing tyrannically locks them into a visual field forever." [12]

${ }^{3}$ Mivel a valóság nem illeszthetó a logika merev, statikus szerkezetei közé, ezért használom az illogicitás fogalmát. Nem szándékom tehát vitatni a valóság sajátos logikáját, pusztán arra kivánok rámutatni, hogy e sajátos logika megjelenítésére a modern formalizmus inadekvát.

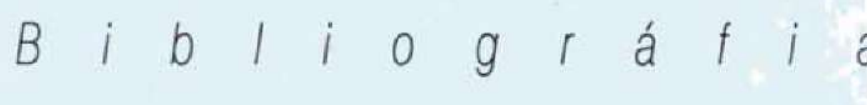

[1] Arisztotelész: Nikomakhoszi ctika, Európa K., Bp. 1987

[2] Derrida, J.: Marx kisértetei, Jelenkor K., Pécs 1995

[3] Gadamer, H.-G.: Igazság és módszer, Gondolat K. 1981

[4] Gloy, K.: Filoźffia a "filozófia utáni korban" in: MaFiSZ 1995/5-6.

[5] Heidegger, M.: Lét és idó, Gondolat K., Bp. 1989

[6] Heidegger, M.: A német egyetem önmegnyilatkozása in: Az idó fogalma, Kossuth K. 1992

[7] Lukács Gy:: Mi az ortodox marxizmus \& in: Törénelem és oszzálytudat, Magvetó K. 1971

[8] Lyotard, J.-F: A posztmodern alllapot, Századvég K., Bp. 1993

[9] Nyíri K.: Hagyomány és szóbeliség in: A hagyomány filozófiaja, T-Twins K. - Lukács Archívum, Bp. 1994

[10] Marx, K.: A politileai gazdaságtan bírálatának alapvonalai, Bp. 1984

[11] Marx, K.: Gazdasági-filozofiai kéziratok 1844-bol, Bp. 1970

[12] Ong, W. J.: Orality and Literacy: The Technologizing of the Word, Methuen K. London - New York, 1982

[13] Platón: Az állam, Gondolat K., Bp. 1989

[14] Rickert, Heinrich: A filozófia alapproblémái, Európa K., Bp. 1987

[15]Russell: Miszticizmus és logika, A tudomány helye az általános müveltségrevaló nevelesben in: Miszticizmus és logika és egyéb tanulmányok, Magyar Helikon K. 1976

[16] Schnädelbach: Morbus Hermeneuticus in: MaFiSZ 1985/3-4.

[17] Weber: A tudomány mint hivatás in: A tudomány és politika mint hivatás, Kossuth K. 1995

[18] Wittgenstein, Ludwig: Filozófiai vizsgalódások, Atlantisz K, Bp. 1992 